Araştırma Makalesi / Research Article

Geliş tarihi / Received: 30.06.2021

Kabul tarihi / Accepted: 23.09.2021

Atıf İçin: Yıldız S, Deniz S, 2021. Muş İli Damızlık Sığır/Manda Yetiştiricileri Birliklerine Üye İşletmelerin Yem Temini ve Hayvan Besleme Alışkanlıkları. Iğdır Üniversitesi Fen Bilimleri Enstitüsü Dergisi, 11(4): 3280-3291.

To Cite: Y1ldiz S, Deniz S, 2021. Feedstuff Supplying and Animal Feeding Habits of Businesses That Are Members of the Associations of Cattle Breeders and Water Buffalo Breeders of Muş Province of Turkey. Journal of the Institute of Science and Technology, 11(4): 3280-3291.

\title{
Muş İli Damızlık Sığır/Manda Yetiştiricileri Birliklerine Üye İşletmelerin Yem Temini ve Hayvan Besleme
} Alışkanlıkları

\author{
Serhat YILDIZ ${ }^{*}$ Suphi DENİZ
}

ÖZET: Bu çalışma, Muş İli Damızlık Sı̆̆ır (DSYB) ve Manda (DMYB) Yetiştiricileri Birlikleri’ne üye yetiştiricilerin genel durumları, mevcut hayvansal üretim potansiyelleri ile hayvancılık için gerekli yem temini ve hayvan besleme alışkanlıklarının tespit edilerek, işletmelerin temel sorunlarını saptamak ve çözüm önerilerinde bulunmak amacıyla yapılmıştır. Çalışmada, Van Yüzüncü Yıl Üniversitesi DAP (Doğu Anadolu Projesi) Çiftçi Eğitim Merkezi’nde eğitimlere katılan 250 kursiyerlerle yapılan anketler kullanılmıştır. Araştırma sonunda katılımcıların \%85.15'inin 15-50 yaş arasında olduğu, lise ve dengi okul mezunu olanların oranı $\% 21.00$, üniversite mezunu olanların oranı ise, $\% 10.00$ olduğu belirlenmiştir. Kursiyerlerin \%75.71'inin 5-100 da, \%16.06'sının 100-250 da, \%8.29'unun ise, 250 da ve üzeri tarım arazisi işledikleri tespit edilmiştir. İşletmelerde ortalama olarak 37.8 baş her yaştan sığır ve 9.33 baş mandanın olduğu; kaba ve kesif yemleri dışarıdan temin eden işletmelerin oranının sırasıyla \%35.68 ve \%52.50 olduğu; hayvanlarını merada otlatanların oranının \%95.45; yonca yetiştirenlerin oranının $\% 35.57$ ve silaj kullanan işletmelerin oranının da \%50.53 olduğu belirlenmiştir. Katılımcıların \%61.73'ünün hayvanlara verilecek rasyonları, kendilerinin göz kararı ile hazırladıkları, \%17.35'inin ise, rasyon hazırlamayı bilen birinden yardım aldıkları tespit edilmiştir. Yetiştiriciler içinde hayvanların ihtiyaç duydukları tuz ve vitamin-mineral takviyelerini yapanların oranı \%87.63 olarak belirlenmiştir. Yetiştiricilerin çoğunluğunun, hayvanlarını günde iki defa yemledikleri (\%64.97) ve ahır içinde sabit suluğa sahip işletmelerin oranının ise $\% 29.80$ olduğu belirlenmiştir.

Anahtar Kelimeler: Muş ilinde hayvancılık potansiyeli, yem temini, hayvan besleme alışkanlıkları

\section{Feedstuff Supplying and Animal Feeding Habits of Businesses That Are Members of the Associations of Cattle} Breeders and Water Buffalo Breeders of Muş Province of Turkey

\begin{abstract}
This study explored fundamental problems of breeding businesses and proposed solutions upon identifying general circumstances, current animal production potentials, and feedstuff supplying \& animal feeding habits of breeders that were members of the Associations of Cattle Breeders and Water Buffalo Breeders in Muş province, Turkey. Surveys conducted with 250 participants who had training in DAP (Eastern Anatolia Project) Farmer Training Center of Van Yuzuncu Yil University of Turkey were utilized in the study. Of all participants, 85.15\% were aged 15-50, 21.00\% were graduates of high schools or their equivalents, $10.00 \%$ were university graduates. Percentages of participants cultivating agricultural lands totaling 5-100, 100-250, and 250 decares or above were consecutively $75.71 \%, 16.06 \%$, and 8.29\%. On average, businesses had 37.8 head of cattle at all ages and 9.33 head of water buffalo. Percentages of businesses outsourcing coarse fodder and concentrate feed were successively $35.68 \%$ and $52.50 \%$ whilst percentages of businesses using pasture feeding, cultivating clover as feedstuff, and using silage were respectively $95.45 \%, 35.57 \%$, and $50.53 \%$. Of all participants, $61.73 \%$ used the rule of thumb to prepare feed rations to be given to animals, $17.35 \%$ received assistance from a person savvy about formulating feed rations, and $87.63 \%$ provided animals with salt and vitamin-mineral supplements. Most breeders fed their animals twice a day (64.97\%) and the percentage of businesses with water drinkers fixed inside the barn was $29.80 \%$.
\end{abstract}

Keywords: Livestock potential in Muş province, feedstuff supply, animal feeding habits,

1 Serhat YILDIZ (Orcid ID: 0000-0003-1063-4704), Van Yüzüncü Yıl Üniversitesi, Gevaş Meslek Yüksekokulu Veterinerlik Bölümü, Van, Türkiye

${ }^{2}$ Suphi DENIZ (Orcid ID: 0000-0002-6005-0056), Van Yüzüncü Yıl Üniversitesi, Veteriner Fakültesi, Hayvan Besleme ve Beslenme Hastalıkları Bölümü, Van, Türkiye

*Sorumlu Yazar/Corresponding Author: Serhat YILDIZ, e-mail: syildiz@yyu.edu.tr

ETIK KURUL ONAYI / ETHICS COMMITTEE APPROVAL: Bu makale, Van Yüzüncü Yıl Üniversitesi Fen ve Mühendislik Bilimleri Yayın Etik Kurulu'nun 15/10/2020 tarih ve 2020/07-01 sayılı kararı gereğince; uygulanmasında herhangi bir sakınca olmadığına karar verilmiştir. 


\section{GÍRIȘ}

Ülkemizin Doğu Anadolu Bölgesi'nde bulunan Muş ilinde hayvancılık önemli bir yere sahiptir. İl genelinde 324850 baş sığır ve 7031 baş da manda bulunmaktadır. Büyükbaş hayvan sayısında Türkiye 15'incisi, manda yetiştiriciliğinde ise 6'ncı sırada yer almaktadır. Yem bitkisi ekilişi 61612 ha arazide 1515000 ton yem bitkisi üretimi yapılarak, ihtiyaç duyulan kaba yemlerin \%78'si karşılanmakta ve yonca üretiminde Türkiye'de 4. üncü sırada yer almaktadır. İl genelinde hayvan beslemede önemli bir değer oluşturan çayır ve meraların (3 $716350 \mathrm{da}$ ) fazla olması, Muş (165 000 ha.), Bulanık (52 250 ha.), Malazgirt (45 000 ha.) ve Liz Ovaları gibi geniş ovalara sahip olması, ilde birçok yem fabrikasının bulunması, sığırcılık faaliyetinin sürdürülebilirliği noktasında önemli bir etkendir. Ancak uzun ve sert geçen kış aylarından dolayı meradan faydalanma süresi kısalmakta ve yaklaşık yılın yarıdan fazlasında hayvanların ahırlarda barındırılması gerekmektedir (Bakır ve Kibar, 2019a; Anonim, 2021).

Muş ili, sosyo-ekonomik olarak ülkemizin geri kalmış illerinden birisidir. Ekonomideki geri kalmışlığın nedenleri arasında; tarımsal faaliyetlerde geleneksel yöntemlerin uygulanması ve yeterince tarımsal mekanizasyona yer verilmemesi, arazilerin parçalanmış olması, mera ve otlak alanlarının bilinçsizce kullanılması, hayvancılıkta teknolojiden yeterince faydalanılamaması ve yeterli organize olunamaması ile hayvan sağlı̆̆ına önem verilmemesi, devlet teşviklerinin yeterince yapılmamış olması, sermayenin yetersiz oluşu, eğitim seviyesinin düşüklüğü ve kalifiye eleman yetersizliği, yeterli ve nitelikli yatırımcıya sahip olunamaması, iklim şartlarının çetin oluşu, terörle mücadele ve göç sorunları, ilde yetiştirilen doğal gıdalar için yeterli pazarlama stratejileri oluşturulamaması sayılabilmektedir (Arslan, 2018).

Muş ilinde hayvancılığın tarımsal faaliyet içinde özel bir önemi bulunmaktadır. Hayvancılık faaliyetlerinin, özelde büyükbaş hayvancılığın ön plana çıkmasındaki en büyük pay, doğal çayır ve meraların bir hayli fazla olması, tarım arazilerinin kirletilmemiş olması, kırsal kesimde yaşayan kişi sayısının fazla olması gibi faktörlerdir. Bunun yanında, mevsimsel olaylardan olan uzun ve sert geçen kış ayları, tarımsal faaliyetleri ve hayvancılık faaliyetlerini sınırlamaktadır. Bundan dolayı hayvancılık faaliyetlerinin ekseriya ekstansif hayvancılık şeklinde yapılmasına neden olmaktadır. Ayrıca kış aylarının uzun geçmesi, hayvanların yılın büyük bir bölümünde kapalı ahırlarda kalmasına yol açmaktadır. Muş ilinde faaliyet gösteren hayvancılık işletmelerinde görülen diğer sorunlardan bazıları ise; desteklemelerin yetersiz oluşu, yem özellikle kaba yem temini sıkıntısı, hayvan yetiştiriciliği ve beslenmesi konularında yeterince bilgiye sahip olunmaması, kredi ve veterinerlik hizmetlerinin yetersiz ve pahalı olması şeklinde sıralanabilmektedir (Bakır ve Kibar, 2019a; Bakır ve Kibar, 2019b).

Ülkemizin genelinde olduğu gibi, Muş ilinde de nüfusun çoğunluğu (\%60) kırsal kesimde yaşamaktadır. $\mathrm{Bu}$ oranın yüksek olması tarım ve hayvancılık açısından ili, avantajlı bir hale getirmektedir. Sınırlı miktarda kullanılabilir arazi kaynakları ve sınırlı üretim kaynaklarından en iyi şekilde yararlanmak suretiyle, kırsal kesim insanlarına daha iyi bir yaşam düzeyi ve yüksek hayat standartları sağlanmış olacaktır (Arslan, 2018; Anonim, 2021). Bundan dolayı, tarım ve hayvancılıkla uğraşan Muş İli DSYB ve/veya DMYB'ne üye yetiştiricilerin genel durumları ile mevcut hayvansal üretim kapasitelerini belirlemek, hayvancılık için gerekli olan yem temini ve hayvan besleme alışkanlıklarını belirlemek, üretimi azaltan temel sorunların tespit edilerek çözüm önerileri sunmak amacıyla, bu çalışma Van YYÜ DAP Çiftçi Eğitim Merkezi’nde gerçekleştirilmiştir.

\section{MATERYAL VE METOT}

Araştırma materyalini, tamamı Muş İli DSYB ve DMYB'ne üye olan ve Van Yüzüncü Yı1 Üniversitesi DAP Çiftçi Eğitim Merkezi’nde düzenlenen eğitimlere katılan, 250 kursiyer ile yüz yüze 
yapılan anketlerden elde edilen veriler oluşturmuştur. Düzenlenen eğitim faaliyetlerine, Muş ili Merkez, Bulanık, Hasköy, Korkut, Malazgirt ve Varto ilçelerinden katılımlar gerçekleşmiştir. Eğitimlere katılan kursiyerlerin seçimi birlikler tarafından yapılmış ve katılımcılar beşer günlük süt sığırı yetiştiriciliği ve manda yetiştiriciliği eğitimleri almışlardır. Eğitimlere katılan tüm işletme sahipleri ankete dahil edilmiştir. Anket çalışması Kasım 2019 ile Mayıs 2020 tarihleri arasında gerçekleştirilmiştir. Verilerin değerlendirilmesi SAS (2014) paket programı ile yapılmış ve bazı bulgulara ki-kare $\left(\chi^{2}\right)$ testi uygulanmıştır.

\section{BULGULAR VE TARTIŞMA}

\section{Ĕgitimlere Katılan Çiftçilerin Bazı Özellikleri}

Araştırmaya konu olan ve DAP Çiftçi Eğitim Merkezi'nde eğitim alan, Muş ili Damızlık Sığır/Manda Yetiştiricileri Birliği üyesi kursiyerlerin \%85.15'inin 15-50 yaş arasında olduğu ve genç bir kitlenin büyükbaş hayvan eğitimi almış olmasının, tarım ve hayvancılığın geleceği açısından umut verici olduğu düşünülmektedir (Çizelge 1). Edirne ili Lalapaşa ilçesinde verilen süt sığırcılığı eğitimi ve bu eğitimi alan kişilerin durumlarının değerlendirildiği bir çalışmada (katılımcıların \%95'inin 18-50 yaş aralığında olduğu bildirilmiştir (Şevik, 2017). Karaturhan ve ark. (2014), tarımsal kalkınmada yetiştirici birliklerinin önemini, Edirne DSYB örnek olayı ile ortaya koyma amacıyla yaptıkları çalışmada, ankete katılanlardan \%75'inin 25-55 yaş arasında olduğunu tespit etmişlerdir. Van ilinde yapılan bir başka çalışmada, çiftçilerin örgütlerden beklentileri ve örgütlenme düzeyi tespit edilmiş, ankete katılanlardan 22-50 yaş aralığında olanların oranının, \%62.7 olduğu belirlenmiştir (Terin ve Ateş, 2010). Bakır ve Kibar (2019a)'ın yapmış olduğu bir araştırmada ise, Muş İlinde bulunan süt sığırcılığı işletmeleri sahiplerinin \%71.9'unun 30-50 yaş aralığında olduğu belirlemiştir.

Çizelge 1. Eğitim alan yetiştiricilerin bazı özellikleri

\begin{tabular}{|c|c|c|c|}
\hline YERLEŞİM YERİ & $\%$ & YASS & $\%$ \\
\hline Bulanık & 27.23 & 15- 20 yaşları arası & 3.47 \\
\hline Hasköy & 2.97 & 21-30 yaşları arası & 29.70 \\
\hline Korkut & 2.97 & $31-40$ yaşları arası & 26.24 \\
\hline Malazgirt & 3.96 & $41-50$ yaşları arası & 25.74 \\
\hline Merkez & 55.94 & 51-60 yaşları arası & 12.38 \\
\hline Varto & 6.93 & 61 yaş ve üzeri & 2.48 \\
\hline ÖĞRENIM DURUMU & & $\begin{array}{l}\text { YAPILAN HAYVANCILIK İÇİN } \\
\text { EĞİTIM ALINIP ALINMADIĞI }\end{array}$ & \\
\hline Okur-yazar değil & 3.00 & Aldım & 20.00 \\
\hline Okur-yazar & 3.50 & Almadim & 80.00 \\
\hline İlkokul mezunu & 38.00 & & \\
\hline Ortaokul mezunu & 24.50 & & \\
\hline Lise mezunu & 21.00 & & \\
\hline Üniversite & 10.00 & & \\
\hline
\end{tabular}

Ankete katılan, Muş ili Damızlık Sı̆̆ır/Manda Yetiştiricileri Birliği üyesi kursiyerlerin eğitim düzeyleri incelendiğinde, \%3.00'ünün okur-yazar olmadığı, \%3.50'sinin okur-yazar, \%38.00'inin ilkokul mezunu, \%24.50'sinin ortaokul mezunu, \%21.00'inin lise ve dengi okul mezunu, \%10.00'unun üniversite mezunu olduğu tespit edilmiştir (Çizelge 1). Katılımcıların büyük çoğunluğunun (\%80.00) şu anda yaptıkları hayvancılık faaliyetleri için başka bir yerden eğitim almadıkları görülmüştür. Yapılan bir araştırmada, anket kapsamında görüşme yapılan işletme sahiplerinin \%8.0’inin okur yazar olmadığ1, \%38.4'ünün ilkokul ve \%2.4'ünün de üniversite mezunu olduğu belirlenmiştir (Şeker ve ark. 2012). Yıldız ve ark. (2019a) tarafından yapılan bir araştırmada, çalışmaya dahil edilen okuma yazma bilmeyen kursiyerlerin oranı \%9.77, okur-yazar olanlar \%8.20, ilkokul mezunu \%39.06, ortaokul mezunu \%21.88, lise ve dengi okul mezunu \%14.84 ve üniversite mezunu olanların oranı ise \%5.86 
olarak tespit edilmiştir. Yıldız ve ark. (2019b) tarafından yapılan başka bir araştırmada, okur-yazar olmayanların oranı \%13.36, okur-yazar olanlar \%19.43, ilkokul mezunu \%22.27, ortaokul mezunu $\% 19.03$, lise ve dengi okul mezunu \%10.93, üniversite mezunu olanlar ise \%4.45 olarak bildirilmiştir. Bakır ve Kibar (2019a)'ın yapmış olduğu bir araştırmada, işletmecilerin eğitim seviyesi \%9.1 okuryazar olmayan, \%51.5 ilkokul, \%24.6 ortaokul, \%13.5 lise ve \%1.5 üniversite mezunu şeklinde tespit edilmiştir.

Araştırma konusu olan Muş ili DSYB/DMYB üyesi kursiyerlerin yerleşim yerleri; Merkez \%55.94, Bulanık \%27.23, Hasköy \%2.97, Korkut \%2.97, Malazgirt \%3.96 ve Varto \%6.93 şeklinde gerçekleşmiştir (Çizelge 1). Bakır ve Kibar (2020), Muş İlinde bulunan besi işletmelerinin bazı yapısal özelliklerini inceledikleri bir araştırmada, araştırmaya katılanların yerleşim yeri dağılımları yaklaşık olarak, Merkez \%16.48, Bulanık \%24.73, Hasköy \%3.85, Korkut \%19.23, Malazgirt \%20.33 ve Varto \%15.33 şeklinde bildirilmiştir. Aynı araştırıcıların, Muş ilinde bulunan süt sığırcılığı işletmelerinin bazı yapısal özelliklerini belirledikleri başka bir araştırmada ankete katılanların yerleşim yeri dağılımları Merkez \%15.65, Bulanık \%31.59, Hasköy \%6.09, Korkut \%6.96, Malazgirt \%23.77 ve Varto \%15.94 şeklinde tespit edilmiştir (Bakır ve Kibar, 2019a).

\section{İşletmelerin Genel Durumu}

Ülkenin gelişmişlik düzeyi, hayvansal üretim ve tüketim artışlarına paralel olarak artmakta, hayvansal üretim miktarlarının artmasında önemli olan kaliteli ve ucuz yem bitkisi üretilebilmesi açısından tarım arazilerinin önemi büyüktür (Özkan, 2020). Bu önemi dikkate alındığında, Muş ili Damızlık Sığır/Manda Yetiştiricileri Birliği üyesi olan ve Van YYÜ DAP Çiftçi Eğitim Merkezi'nde eğitimlere alan yetiştiricilerin \%75.71'i 5-100 da, \%16.06's1 100-250 da, \%8.29'u ise, 250 da ve üzeri tarım arazisini işledikleri tespit edilmiştir (Çizelge 2). Ağrı ilindeki sığırcılık işletmelerinin sosyoekonomik özelliklerinin araştırıldığı bir çalışmada, incelenen işletmelerin sahip oldukları arazi büyüklüğü ortalama olarak 111.4 da olarak belirlenmiştir (Bakan ve Aydın, 2016). Turan (2019), Diyarbakır manda yetiştiriciliğinin mevcut durumu ve sorunlarını incelediği bir çalışmada, 112 işletmenin arazi varlığı ortalamasını 174.9 da olarak bulurken; Güzel ve Aybek (2017), işletmelerin arazi varlığını ortalama olarak 156 da olarak hesaplamıştır.

Gelir düzeyi, insanların yaşam kalitesini artıran faktörlerden biri olarak görülmektedir (Yıldız ve ark., 2019b). DAP Çiftçi Eğitim Merkezi'nde verilen eğitimlere katılan kursiyerlerin aylık gelirleri incelendiğinde, büyük çoğunluğunun gelirinin 3000 TL'sinin altında (\%86.11) olduğu belirlenmiştir (Çizelge 2). Türkiye'deki sürekli tarım işçilerinin ortalama aylık ücretleri, 2018 yılı tarımsal işletme işgücü ücret yapısı istatistiklerine göre, 2117 TL (TÜIK, 2018) olarak bildirilmektedir. Yıldız ve ark (2019b)'ın yaptığı bir araştırmada, aylık gelirleri 3000 TL'nin altında olan işletme sahiplerinin oranı \%70,30 olarak tespit edilmiştir. Başka bir araştırmada, üreticilerin ortalama aylık gelirlerinin $1155 \mathrm{TL}$ olduğu ve bu miktarın yoksulluk sınırının altında olduğu belirlenmiştir (Karadavut ve ark., 2011).

Gün geçtikçe gelişen ve farklılaşan zirai alet ve makineleri bugün tarımsal faaliyetlerle uğraşanların vazgeçilmez bir yardımcısıdır. Günümüzde işlerin zamanında bitirilmesi, bitkisel üretim ve hayvancılık yapmayı kolaylaştırması, zirai alet ve makinaların önemini artırmaktadır (Kabaş, 2021). Bu çalışmada, katılımcıların birçok zirai alet ve makinelere sahip olduğu, fakat en fazla sahip oldukları zirai makinenin traktör olduğu (\%37.57) belirlenmiştir (Çizelge 2). Ancak, yem kırma makinas1 (\%3.17), yem karıştırma makinası (\%2.12), balya makinası (\%3.17) ya da süt sağım makinasına (\%4.76) sahip yetiştiricilerin oranının oldukça düşük olduğu tespit edilmiştir. Ağrı ilindeki sığırcılık işletmelerinin sosyo-ekonomik özelliklerinin incelendiği bir araştırmada, işletmelerin \%80.2'sinde en 
çok bulunan ekipmanın traktör olduğu belirlenmiştir (Bakan ve Aydın, 2016). İşletmelerdeki traktör oranın1, Güzel ve Aybek (2017), \%76; Y1ldız ve ark. (2019b) ise \%68.15 olarak tespit etmişlerdir.

Tarımsal örgütlenme, birlikte karar alabilen ve sorumluluk bilinciyle hareket eden insanların, bir araya gelerek ortak bir sinerji geliştirdikleri bir organizasyon olarak ifade edilmekle birlikte, üreticilerin etkili bir biçimde örgütlenmesiyle de, tarımsal üretimin artırılması, kaliteli ürün elde edilmesi ve tarım ile uğraşanların yaşam düzeylerinin yükseltmesi sağlanmış olacaktır (Karaturhan ve ark., 2014; Taşan, 2019). Bu çalışmada ankete katılanlar, Muş ili Damızlık Sığır/Manda Yetiştiricileri Birliği üyesi kişilerden oluştuğu için, katılımcıların tamamı, tarımsal bir örgüte üyedir (Çizelge 2). Bakır ve Kibar (2020) yaptıkları bir çalışmada, Muş ilinde bulunan besi sığırcılığı ile uğraşan yetiştiricilerin \%39.3'ünün birliğe ve \%15.9'unun kooperatife üye olduklarını bildirmişlerdir. Ağrı ilinde yapılan bir diğer çalışmada, işletme sahiplerinin \%96.2'sinin herhangi bir birlik veya kooperatife üye olmadıkları belirlenmiştir (Bakan ve Aydın, 2016). Turan (2019)'ın yaptığı bir çalışmada, yetiştiricilerin \% 72.8'inin tarımsal bir örgüte üye oldukları belirlenmiştir.

Çizelge 2. İşletmelerin genel durumu

\begin{tabular}{|c|c|c|c|}
\hline $\begin{array}{l}\text { KULLANILAN TARIM ARAZISİ } \\
\text { MIKTARI (DA) }\end{array}$ & $\%$ & $\begin{array}{l}\text { HAYVANCILIKTA KULLANILAN ZİRAİ } \\
\text { ALET VE MAKİNALAR }\end{array}$ & $\%$ \\
\hline 5-20 dönüm & 19.69 & Traktör & 37.57 \\
\hline 20-50 dönüm & 26.42 & Yem karıştırma makinası & 2.12 \\
\hline 50- 100 dönüm & 29.53 & Yem kırma makinası & 3.17 \\
\hline 100-250 dönüm & 16.06 & Süt sağım makinası & 4.76 \\
\hline 250-500 dönüm & 4.15 & Balya makinası & 3.17 \\
\hline 500-1 000 dönüm & 2.59 & Diğger & 28.04 \\
\hline 1000 dönüm ve üzeri & 1.55 & İki veya daha fazla parametre seçenler* & 21.16 \\
\hline TARIMSAL ÖRGÜTLERE ÜYELİK & & AYLIK GELİR (TL) & \\
\hline Hiçbirine üye değilim & 0 & 2000 den az & 62.22 \\
\hline Tarımsal kalkınma kooperatifine & 0.50 & $2001-3000$ aras 1 & 23.89 \\
\hline Sulama kooperatifine & 0 & $3001-4000$ aras 1 & 6.67 \\
\hline Tarım kredi kooperatifine & 0.50 & $4001-5000$ aras 1 & 4.44 \\
\hline DSYB'ne & 42.79 & 5001 ve üzeri & 2.78 \\
\hline DMYB'ne & 1.00 & TARIMSAL DESTEK DURUMU & \\
\hline İki parametre seçenler ${ }^{*}$ & 51.74 & Evet & 48.02 \\
\hline Üç parametre seçenler* & 2.99 & Hayır & 51.98 \\
\hline Dört parametre seçenler* & 0.50 & & \\
\hline HAYVAN SAYILARI & EN AZ & EN ÇOK & ORTALAMA \\
\hline İnek & 1 & 200 & 13.85 \\
\hline Manda & 1 & 30 & 9.33 \\
\hline Düve & 1 & 45 & 5.76 \\
\hline Dana & 1 & 45 & 7.37 \\
\hline Buzağ 1 & 1 & 240 & 8.53 \\
\hline Boğa & 1 & 20 & 2.29 \\
\hline
\end{tabular}

*Bu sorularda birden fazla parametre seçilmiştir

Tarımsal ürünler stratejik oldukları için, dünyanın birçok ülkesi tarım sektörlerine destek vermektedir. Tarım sektörünün gelişmesinde ve sürdürülebilirliğin sağlanmasında, örgütlenme ve desteklemeler önem arz etmektedir. Tarımsal desteklemeler, tarımsal gelirlerin artırılmasında; verimliliğin artırılması, kalitede iyileşme ve üretimde istikrar gibi nedenlerle önemli roller üstlenmektedir (Akın ve ark., 2018). İşletmelerin gelişip daha iyi faaliyet gösterebilmeleri açısından önem arz eden tarımsal desteklemeler, yapılan bu çalışmada değerlendirilmiş ve işletmelerin \%48.02'inin tarımsal desteklerden faydalandıkları tespit edilmiştir (Çizelge 2). Ağrı ilinde yapılan bir çalışmada, işletmelerin tamamına yakınının herhangi bir tarımsal destekten faydalandığı belirlenmiştir (Bakan ve Aydın, 2016). Aksoy ve ark. (2014), birliğe üye olan işletmelerin herhangi bir tarımsal 
destekten faydalanma oranını \%46.6; Y1ldız ve ark. (2019b) \%41.82; Demir ve ark. (2015) ise, \%87.9 olarak bildirmişlerdir.

$\mathrm{Bu}$ araştırma kapsamında incelenen, Muş ili Damızlık Sığır/Manda Yetiştiricileri Birliği üyesi işletmelerin, işletme başına ortalama olarak 37.8 baş her yaştan sı̆̆ıra, 9.33 baş mandaya sahip oldukları belirlenmiştir (Çizelge 2). Bakır ve Kibar (2019a), Muş ilinde bulunan süt sığırcılığı işletmelerindeki hayvan sayısını ortalama olarak 56.6; Akkurt ve Köknaroğlu (2016), Isparta ilinde işletme başı hayvan sayısını 53; Bakan ve Aydın (2016) Ağrı ilinde bu sayıyı 19.9 baş olarak belirlemişlerdir. Turan (2019) ise, Diyarbakır ilinde ortalama manda sayısını, işletme başına 11.03 baş şeklinde bildirmektedir.

\section{İşletmede Yem Temini}

Önemli yem kaynaklarından olan yem bitkileri ve doğal çayır meralar, hayvanlara kaliteli, ucuz ve bol kaba yem sağlamada ön plana çıkmaktadır. Hayvan beslemede ucuz bir kaynak olan kaliteli kaba yemler, ruminantların rumen mikro florası için gerekli besinleri sağlayan, hayvanların üreme gücünü arttırılmasında etkili olan, beslenmeyle ilgili birçok metabolik hastalığı önlemeye yardımcı olan özellikleri nedeniyle üzerinde önemle durulmaktadır. Ayrıca, tarım arazilerinin fiziksel ve kimyasal özelliklerini ve kendisinden sonra ekilen bitkilerin verim ve kalitesine olumlu etkide bulunmaları açısından da önemlidirler (Soya ve ark. 2004). Bu çalışmada, eğitimlere katılan kursiyerlerin, hayvanların ihtiyacı olan kaba yemleri, kendi yetiştirenlerin oranının \%22.11, dişarıdan temin edenlerin oranının \%35.68 ve hem kendi yetiştiren hem satın alanların oranının ise \%42.21 olduğu belirlenmiştir (Çizelge 3). Yıldız ve ark. (2019b), işletmenin ihtiyacı kaba yemlerin, \%46.55'inın kendileri tarafından üretildiğini, \%21.55'inin dışarıdan satın alındığını, \%18.97'inin ise, hem kendileri tarafından üretildiği, hem de işletme dışından satın alındığını saptamıştır. Karakuş ve Akkol (2013) tarafından yapılan bir çalışmada, kaba yemlerin \%12.26'ının işletmenin kendisinden, \%17.22'inin dışarıdan satın alındığı, \%70.52'inin ise, hem kendilerinin ürettiği, hem de işletme dışından satın alındığı bildirilmektedir. Boz (2013), işletmelerin kaba yem ihtiyacının temin edilme durumunu incelemiş ve işletmelerin \%44.4'ünün kaba yemleri kendilerinin ürettiği ve \%28.8'inin yem bayiinden temin ettiklerini tespit etmiştir. Yapılan başka bir araştırmada, işletmelerin çoğunluğunun (\%52.26) kaba yemleri kendi işletmesinde ürettiği tespit edilmiştir (Demir ve ark., 2013).

Çalışmaya katılan kursiyerlerin, 2-5 farklı kaba yemi karıştırarak (\%59.01) hayvanlarına verdikleri belirlenmiştir. Yapılan bir araştırmada, Van ilinde üreticilerin sığır besisi işletmelerinde en çok buğday ve arpa samanı (\%87), yonca (\%66), korunga (\%35), çayır kuru otu (\%45) ve mercimek samanı (\%54) kullanıldığı bildirilmektedir (Budă̆ ve Keçeci, 2013). Yapılan bir çalışmada ele alınan işletmelerde kaba yem kaynağı olarak, \%84.1'inin saman, \%72.2'sinin kuru ot, \%15.3'ünün kes ve \%12.8'inin ise, yaş şeker pancar posası kullanıldığı tespit edilmiştir (Bakır ve Demirel, 2001). Yapılan başka bir araştırmada ise, işletmede kullanılan kaba yemlerin \% 75.41'inin saman, \%45.08'inin yonca, \%23.77'inin korunga ve \%4.92'inin çayır otundan oluştuğu belirlenmiştir (Şahin ve Yılmaz, 2008a).

Kesif yemler, protein ve enerji bakımından zengin, gerek süt hayvanları, gerekse besi hayvanlarının beslenmesinde, kaba yemlerle birlikte kullanılan yemlerdir. Hayvanların dengeli ve sağlıklı beslenmelerinde, hayvansal ürünlerin kalitesinin yükseltilmesinde ve işletme karlılığının arttırılmasında büyük önem taşımaktadır (Gülsün ve Miç, 2018). Yapılan bu çalışmaya katılan kursiyerlerin, hayvanların ihtiyacı olan kesif yemleri temin noktasında, kendi yetiştirenlerin oranının $\% 11.50$, dışarıdan temin edenlerin oranının $\% 52.50$ ve hem kendi yetiştiren hem satın alanların oranının ise \%36.00 olduğu tespit edilmiştir (Çizelge 3). Yıldız ve ark. (2019b), ankete katılanların hayvan beslemede kullandıkları kesif yemlerin, \%23.11'ini kendilerinin ürettiği, \%43.56'ını dışarıdan 
satın aldığı, \%25.33'ünün de, hem kendilerinin ürettiği, hem de işletme dışından satın aldıkları bildirilmiştir. Karakuş ve Akkol (2013), kesif yemlerin \%5.65'inin işletmede üretildiği, \%15.86'1nın dışarıdan satın alındığı, \%78.49'unun ise, hem kendilerinin ürettiği, hem de işletme dışından satın aldıklarını belirlemişlerdir. Boz (2013), işletmelerin kesif yem ihtiyacının temin edilme durumunu incelemiş ve çoğunluğun kesif yemleri yem bayiinden (\%54.4) ve yem fabrikasından (\%20.6) temin ettiklerini tespit etmiştir. Bu çalışmaya katılan kursiyerlerin, hayvanları beslemek için kullandıkları kesif yemleri de 2-5 farklı kesif yemi (\%50.55) karıştırarak verdikleri, bu oranın yüksek olmakla birlikte sadece arpa kırması (\%27.27) ya da kepek (\%15.66) kullanarak hayvanlarını besleyenlerin de olduğu belirlenmiştir. Esen (2017), Bingöl ilinde büyükbaş hayvancılık işletmelerinde mera döneminde sağmal ineklere kesif yem kullanan işletmelerin oranının \%25.80 olduğu bildirilmiştir. Yapılan başka bir araştırmada, çalışmada ele alınan işletmenin \%71.5'i kesif yem kaynağı olarak kepek, \%69.3'ü süt yemi, \%5.6'sı arpa kırığı ve \%2.2'si de besi yemi kullandığ1 tespit edilmiştir (Bakır ve Demirel, 2001).

Çizelge 3. İşletmede yem temini

\begin{tabular}{|c|c|c|c|}
\hline KABA YEMLERİN TEMINİ & $\%$ & $\begin{array}{l}\text { İŞLETMEDE YETİŞTİRİLEN YEM } \\
\text { BİTKİLERİ }\end{array}$ & $\%$ \\
\hline Kendi yetiştiriyor & 22.11 & Yonca & 35.57 \\
\hline Dişarıdan satın alıyor & 35.68 & Korunga & 2.06 \\
\hline Hem kendi yetiştiriyor hem satın alıyor & 42.21 & Fiğ & 1.03 \\
\hline KABA YEMLERIN TEMINI & & Silajlik misır & 3.09 \\
\hline Kendi yetiştiriyor & 11.50 & Diğer & 23.71 \\
\hline Dişarıdan satın alıyor & 52.50 & İki parametre seçenler* & 28.87 \\
\hline Hem kendi yetiştiriyor hem satın alıyor & 36.00 & Üç parametre seçenler* & 4.64 \\
\hline $\begin{array}{l}\text { TUZ VE VİTAMİN-MİNERAL } \\
\text { TAKVIYYESİ YAPILMASI }\end{array}$ & & Dört veya daha fazla şık seçenler* & 1.04 \\
\hline Evet & 87.63 & HAYVANLAR MERAYA ÇIKIYOR MU? & \\
\hline Hayır & 12.37 & Evet & 95.45 \\
\hline SÍLAJ YEMİ KULLANILIYOR MU? & & Hayır & 4.55 \\
\hline Evet & 50.53 & & \\
\hline Hayır & 49.47 & & \\
\hline
\end{tabular}

* Bu sorularda birden fazla parametre seçilmiştir

Yapılan bu araştırmada, çalışmaya katılan işletmeler içinde sadece yonca yetiştiriciliği yapan işletmelerin oran $\% 35.57$ iken, sadece silajlı mısır, korunga ve fĭg yetiştiren işletmelerin oranı ise sırasıyla \%3.09, \%2.06 ve \%1.03 gibi düşük seviyede kalmıştır. İki ve daha fazla yem bitkisini beraber yetiştirenlerin oranı ise \%58.25 olarak belirlenmiştir (Çizelge 3). Yapılan bir çalışmada, süt sı̆̆ırcılığı işletmelerinde, ortalama işlenen alan, işletme başına 14.55 da olmuş, bunun 5.0 da'1 buğday, 4.14 da'1 yonca, 3.12 da'1 arpa, 1.05 da'1 silajlık mısır ve 0.60 da'ının da korunga olduğu bildirilmiştir (Şahin ve Gürsoy, 2016). Şahin ve Yılmaz (2008a)'in yaptı̆̆ bir çalışmada, ele alınan işletmelerde yem bitkisi ekim alanlarının ortalama 29.38 da, bunun 20.67 da'1 yonca ve 8.71 da'ının ise korunga olduğu; aynı araştırıcıların yaptığı benzer bir çalışmada, ortalama yem bitkileri ekim alanı 26.87 da, bunun 20.14 da'1 yonca, 5.34 da'1 korunga ve 1.39 da'ının ise silajlık mısır olduğu belirlenmiştir (Şahin ve Yılmaz, 2008b). Yapılan bir çalışmada, Kars ili süt sığırcılığı işletmelerinde yem kullanımı ve hayvan besleme alışkanlıklarının ekonomik önemi üzerinde durulmuş, işletmelerin \%88.7'sinde yem bitkisi üretildiği ve yem bitkileri içinde de en fazla korunga ve fiğ üretiminin yapıldığg bildirilmiştir (Demir ve ark., 2013). 
$\mathrm{Bu}$ çalışmada ele alınan işletmelerdeki yetiştiriciler içinde hayvanların ihtiyacı olan tuz ve vitamin-mineral takviyesini \%87.63'ünün yaptığı, \%12.37'sinin ise yapmadıkları belirlenmiştir (Çizelge 3). Yıldız ve ark (2019b), ankete katılan yetiştiricilerin \%86.94'ünün tuz ve vitamin-mineral katkısı yaptıkları, \%13.06'sının ise yapmadıklarını bildirirken; Karakuş ve Akkol (2013), tuz ve vitamin-mineral takviyesini \%57.95'inin yaptığı, \%42.05'inin ise yapmadıkları bildirilmiştir.

Hayvanların meradan yararlanması, işletme giderlerinin azaltılması ve sağlıklı bir hayvan yetiştiriciliği için önem arz etmektedir (Kara ve Kızıloğlu, 2013). Yapılan bu çalışmada, işletme sahiplerinin çoğunluğunun hayvanlarını merada otlattıkları (\%95.45) tespit edilmiştir (Çizelge 3). Yıldız ve ark. (2019b) tarafından yapılan bir araştırmada, ankete katılan yetiştiricilerin \%90.87'sinin hayvanlarını meraya çıkarttıkları bildirilmiştir. Şahin ve Yılmaz (2008a), bu oranı \%76.22 olarak bildirmişlerdir. Turan (2019) tarafından yapılan bir çalışmada, ankete katılan yetiştiricilerin \%36.7'si mandalarını tek bir sürü halinde merada otlatırken, \%63.3'ü mandalarını sığırlarla bir arada merada otlattıklarını bildirmişlerdir. Esen (2017) hayvanların meraya çıkarılma oranını \%97.93 olarak bildirirken; Demir ve ark. (2013) ise, işletmelerin \%87.6'sının yılın farklı aylarında çayır-mera imkanlarından faydalandığını ifade etmiştir.

Kârlı hayvancılığın önemli bir faktörü olan silajın, bu çalışmada yer alan yetiştiricilerin \%50.53 tarafından kullandığı belirlenmiştir (Çizelge 3). Aksoy ve ark. (2014)'nın yapmış olduğu ve Erzurum ili DSYB'ne üye olan ve olmayan üreticilerin belirli özellikler açısından karşılaştırıldığı bir çalışmada, birliğe üye olan ve silaj yemi yapanların oranı \%11.3 iken, üye olmayanlarda bu oran \%2.0 olarak tespit edilmiştir. Yapılan bir araştırmada, işletmelerin \%88.3'ünün hayvanlarını beslerken silajdan faydalanmadıkları tespit edilmiştir (Demir ve ark., 2013). Yıldız ve ark. (2019b), ankete katılan yetiştiricilerin \%18.40'ının silajı kullanırken; Şahin ve Keskin (2010), silaj kullanım oranını \%25.20 olarak saptamışlardır.

\section{İşletmede Hayvan Besleme Alışkanlıkları}

Katılımcıların \%30.81'i hayvanlarını sulamak için önlerine kendilerinin taşıdığı, \%29.80'inin ise ahır içinde sabit sulukta hayvanlarını suladıkları belirlenmiştir (Çizelge 4). Turan (2019), ankete katılan yetiştiricilerin \%10.2'sinin mandalarını yaz döneminde çeşmede, \%34.7'si çeşme+nehirde ve \%32.7'sinin çeşme+nehir+kuyu suyu ile suladıklarını ifade etmiştir. Yapılan bir çalışmada, işletmelerdeki bazı özellikler ele alındığında, \%34.3'ü taşıma ile, \%34.3'ü yemliklere su doldurarak, \%22.4'ü otomatik suluklarla, \%4.6'sı köy çeşmesinde ve \% 4.3'ünün ise yalaklarda hayvanlarını suladıkları belirlenmiştir (Aydın ve ark., 2016).

$\mathrm{Bu}$ çalışmada, yetiştiricilerin çoğunluğu, hayvanlarını günde iki defa yemlediklerini (\%64.97), yemleme işlemini çuval kullanarak (\%64.80) yaptıklarını ve yoğun yem ile kaba yemler için ayrı yemliklerinin bulunmadığını (\%62.03) belirtmişlerdir (Çizelge 4). Yapılan bir çalışmada, işletme sahiplerinin işgücü değerlendirmesine göre hayvanlarını günde iki defa yemledikleri belirlenmiştir (Güzel ve Aybek, 2017). Bakır (2002), betonarme, ahşap veya saç malzemeden yapılan yemliklerin ahırların tamamında duvara bitişik olduğu, yem yolunun ise bulunmadığı, yemlemenin hayvanların aralarına girilerek zor ve tehlikeli şartlarda yapıldığı bildirilmektedir. Turan (2019), ankete katılan yetiştiricilerin \%73.5'inin işletmelerinde betondan oluşan yemlikleri kullandıklarını belirtirken, \%12.9'unun metal yemlikleri, \%8.8'inin plastik yemlikler ve \%4.8'inin ise tahtadan oluşan yemlikleri tercih ettiklerini ifade etmiştir.

$\mathrm{Bu}$ araştırmada yer alan kursiyerlerin çoğunluğunun hayvanlara verilecek rasyonları, kendileri göz kararı (\%61.73) ile hazırladıklarını; rasyon hazırlamayı bilen birinden yardım alanların oranı ise \%17.35 olarak tespit edilmiştir (Çizelge 4). Yapılan bir çalışmada, hayvanlara verilen kaba ve kesif 
yemlerin hayvanların ihtiyaçlarını tam olarak karşılama bilinciyle değil, bu yemlerin işletmede var olduğu için kullanıldığı, rasyonlarda silajın kullanılmadığı, hayvanların yaşama ve verim durumları dikkate alınmadan beslendiği bildirilmiştir (Bakır ve Demirel, 2001). Yapılan başka bir çalışmada, üreticilerin önemli bir kısmının hayvanları kendi bilgi ve tecrübeleri doğrultusunda besledikleri belirlenmiştir (Demir ve ark., 2013).

Çizelge 4. Hayvan besleme alışkanlıkları

\begin{tabular}{|c|c|c|c|}
\hline $\begin{array}{l}\text { HAYVAN BESLEMEDE } \\
\text { KULLANILAN KABA YEMLER }\end{array}$ & $\%$ & $\begin{array}{l}\text { HAYVAN BESLEMEDE KULLANILAN KESIF } \\
\text { YEMLER }\end{array}$ & $\%$ \\
\hline Buğday-arpa samanı & 11.88 & Buzağ1 yemi & 2.02 \\
\hline Yonca & 14.85 & Süt yemi & 3.54 \\
\hline Korunga & 2.97 & Arpa kırmas1 & 27.27 \\
\hline Çayır otu & 8.42 & Kepek & 15.66 \\
\hline Silaj & 1.49 & Pamuk tohumu küspesi & 3.54 \\
\hline Şeker pancarı posası & 1.49 & İki parametre seçenler* & 22.74 \\
\hline İki parametre seçenler* & 23.79 & Üç parametre seçenler* & 16.17 \\
\hline Üç parametre seçenler* & 18.84 & Dört parametre seçenler* & 8.10 \\
\hline Dört parametre seçenler* & 9.92 & Beş veya daha fazla parametre seçenler* & 3.54 \\
\hline Beş veya daha fazla şı seçenler* & 6.46 & RASYON HAZIRLANIRKEN İZLENILLEN YOL & \\
\hline HAYVANLARI SULANMA ŞEKLİ & & Rasyon hazırlamayı bilen birinden yardım alıyorum & 17.35 \\
\hline Derede & 13.13 & $\begin{array}{l}\text { Komşular ya da arkadaşlarım nasıl hazırlıyorsa ben de } \\
\text { öyle hazırlıyorum }\end{array}$ & 11.22 \\
\hline Köy ortak çeşmesinde & 9.60 & Kendim göz kararı dengeli hazırlıyorum & 61.73 \\
\hline Önlerine ben taşıyorum & 30.81 & Rastgele ve düzensizce hazırlıyorum & 5.61 \\
\hline Ahır içinde sabit sulukta & 29.80 & İki veya daha fazla şık seçenler* & 4.09 \\
\hline Otomatik sulukta & 5.55 & GÜNLÜK YEMLEME SAYISI & \\
\hline İki veya daha fazla şı seçenler* & 11.11 & Günde bir defa & 5.08 \\
\hline YEMLEME ŞEKLİ & & İki defa & 64.97 \\
\hline Yem karma makinasıyla & 5.61 & Üç defa & 25.89 \\
\hline El arabasiyla & 10.71 & Üçten fazla & 4.06 \\
\hline Çuvalla & 64.80 & YEMLİKLERİN DURUMU & \\
\hline Kovayla & 18.88 & $\begin{array}{l}\text { Yoğun ve kaba yemler için ayrı yemlik var } \\
\text { Yoğun ve kaba yemler için ayrı yemlik yok }\end{array}$ & $\begin{array}{l}37.97 \\
62.03\end{array}$ \\
\hline
\end{tabular}

* Bu sorularda birden fazla parametre seçilmiştir

\section{Hayvan Besleme Alışkanlıkları ile Önemli Bazı Parametreler Arasındaki İlişsi}

Muş ili DSYB/DMYB üyesi olan ve Van YYÜ DAP Çiftçi Eğitim Merkezi’nde eğitimler katılan kursiyerlerin hayvan besleme alışkanlıkları ile yaş, öğrenim durumu, hayvancılık eğitimi alma durumu, işlenen tarım arazisi miktarı ve herhangi bir tarımsal organizasyona üyelikleri değişkenleri arasında Khi kare testi uygulanmıştır (Çizelge 5). Çizelge incelendiğinde, katılımcıların öğrenim durumu ile hayvan beslemede kullanılan kaba yemler $(\mathrm{P}<0.05)$ ve hayvanların yemlenme şekli arasında $(\mathrm{P}<0.01)$; hayvancılık eğitimi alma durumu ile hayvan beslemede kullanılan kesif yemler $(\mathrm{P}<0.05)$, hayvanların yemlenme şekli $(\mathrm{P}<0.001)$, rasyonlar hazırlanırken izlenilen yol $(\mathrm{P}<0.05)$ ve hayvan yemliklerinin durumu $(\mathrm{P}<0.01)$ değişkenleri arasında; işlenen tarım arazisi miktarı ile hayvan beslemede kullanılan kaba yemler $(\mathrm{P}<0.05)$, hayvanların yemlenme şekli $(\mathrm{P}<0.001)$ ve rasyonlar hazırlanırken izlenilen yol $(\mathrm{P}<0.001)$ değişkenleri arasında anlamlı bir ilişki olduğu belirlenmiştir. Çalışmaya katılan bireylerin yaşları ve tarımsal organizasyona üyelik parametreleri ile hayvan besleme alışkanlıkları değişkenleri arasında herhangi anlamlı bir ilişki olmadığı belirlenmiştir. 
Çizelge 5: İşletmelerin hayvan besleme alışkanlıkları ile bazı parametreler arasındaki ilişki

\begin{tabular}{|c|c|c|c|c|c|c|c|c|c|c|}
\hline & \multicolumn{2}{|c|}{ Yaş } & \multicolumn{2}{|c|}{$\begin{array}{l}\text { Öğrenim } \\
\text { Durumu }\end{array}$} & \multicolumn{2}{|c|}{$\begin{array}{l}\text { Hayvancılık } \\
\text { eğitimi alma }\end{array}$} & \multicolumn{2}{|c|}{$\begin{array}{c}\text { İşlenen } \\
\text { tarım arazisi }\end{array}$} & \multicolumn{2}{|c|}{$\begin{array}{c}\text { Tarımsal } \\
\text { organizasyonlara üyelik }\end{array}$} \\
\hline & $\chi^{2}$ & $\mathrm{P}$ & $\chi^{2}$ & $\mathrm{P}$ & $\chi^{2}$ & $\mathrm{P}$ & $\chi^{2}$ & $\mathrm{P}$ & $\chi^{2}$ & $\mathrm{P}$ \\
\hline Hayvan beslemede kullanılan kabc & 53.2258 & 0.3511 & 67.7843 & 0.0477 & 15.8106 & 0.1052 & 80.6081 & 0.0392 & 63.7557 & 0.3459 \\
\hline Hayvan beslemede kullanılan kesif yemler & 45.0109 & 0.6734 & 46.0937 & 0.6309 & 20.6013 & 0.0241 & 66.1072 & 0.2742 & 48.0427 & 0.8669 \\
\hline Hayvanların günlük yemleme sayısı & 24.5343 & 0.0566 & 18.8407 & 0.2210 & 2.0192 & 0.5684 & 11.0901 & 0.8905 & 27.3943 & 0.0719 \\
\hline Hayvanların yemlenme şekli & 16.1253 & 0.3738 & 37.5115 & 0.0011 & 42.4437 & 0.0001 & 45.8107 & 0.0003 & 15.3483 & 0.4266 \\
\hline Rasyonlar hazırlanırken izlenilen yol & 28.1941 & 0.2990 & 33.6543 & 0.1155 & 12.4362 & 0.0293 & 105.6595 & 0.0001 & 18.9745 & 0.9405 \\
\hline Hayvanların sulanma şekli & 26.3967 & 0.3867 & 16.6506 & 0.8941 & 4.7288 & 0.4499 & 32.0655 & 0.3645 & 24.4031 & 0.7535 \\
\hline Hayvan yemliklerinin durumu & 4.6450 & 0.4607 & 4.0024 & 0.5491 & 9.0141 & 0.0027 & 3.9596 & 0.6821 & 2.6214 & 0.7581 \\
\hline
\end{tabular}

\section{Yem Temini ile Önemli Bazı Parametreler Arasındaki İlişki}

Çalışmada, hayvanların ihtiyacı olan yem temini ile katılımcıların yaş, öğrenim durumu, hayvancılık eğitimi alma durumu, işlenen tarım arazisi miktarı ve tarımsal bir organizasyona üyelik değişkenleri arasında Khi kare testi uygulanmıştır (Çizelge 6). Çizelge incelendiğinde, ankete katılan bireylerin öğrenim durumu ve tarımsal bir organizasyona üyelikleri ile yem temini değişkenleri arasında anlamlı bir ilişki olmadığı tespit edilmiştir. Katılımcıların yaşları ile kesif yem temin edilme durumu $(\mathrm{P}<0.01)$, hayvancılık eğitimi alma durumu ile hayvanların silaj yemleriyle besleme durumu $(\mathrm{P}<0.001)$ ve işletmede yem bitkileri yetiştirilme $(\mathrm{P}<0.05)$ değişkenleri arasında; işlenen tarım arazisi miktarı ile kaba yem temin edilme durumu $(\mathrm{P}<0.05)$, hayvanların silaj yemleriyle besleme durumu $(\mathrm{P}<0.05)$ ve işletmede yem bitkileri yetiştirme $(\mathrm{P}<0.001)$ değişkenleri arasında anlamlı bir ilişki olduğu belirlenmiştir.

Çizelge 6: İşletmelerin yem temini ile bazı parametreler arasındaki ilişki

\begin{tabular}{|c|c|c|c|c|c|c|c|c|c|c|}
\hline & \multicolumn{2}{|c|}{ Yaş } & \multicolumn{2}{|c|}{$\begin{array}{l}\text { Öğrenim } \\
\text { Durumu }\end{array}$} & \multicolumn{2}{|c|}{$\begin{array}{l}\text { Hayvancılık } \\
\text { eğitimi alma }\end{array}$} & \multicolumn{2}{|c|}{$\begin{array}{l}\text { İşlenen tarım } \\
\text { arazisi }\end{array}$} & \multicolumn{2}{|c|}{$\begin{array}{c}\text { Tarımsal } \\
\text { organizasyonlara } \\
\text { üyelik }\end{array}$} \\
\hline & $\chi^{2}$ & $\mathrm{P}$ & $\chi^{2}$ & $\mathrm{P}$ & $\chi^{2}$ & $\mathrm{P}$ & $\chi^{2}$ & $\mathrm{P}$ & $\chi^{2}$ & $\mathrm{P}$ \\
\hline Kaba yem temin edilme durumu & 12.8814 & 0.2304 & 5.9339 & 0.8208 & 0.0986 & 0.9519 & 22.7300 & 0.0301 & 14.4122 & 0.2752 \\
\hline Kesif yem temin edilme durumu & 25.7487 & 0.0014 & 14.4945 & 0.1516 & 2.1403 & 0.3430 & 18.7277 & 0.0951 & 20.1111 & 0.0650 \\
\hline Hayvanların meraya çıkarılma durumu & 5.0375 & 0.4113 & 8.3158 & 0.1397 & 1.1738 & 0.2786 & 8.2550 & 0.2200 & 2.4230 & 0.8770 \\
\hline Hayvanların silaj yemleri ile besleme durumu & 3.1225 & 0.6811 & 6.7321 & 0.2413 & 15.4979 & 0.0001 & 16.2300 & 0.0126 & 3.9833 & 0.6789 \\
\hline Tuz ve vitamin-mineral takviyesi durumu & 3.5425 & 0.6170 & 4.3560 & 0.4994 & 1.4185 & 0.2336 & 2.9003 & 0.8213 & 0.9728 & 0.9647 \\
\hline İşletmede yem bitkileri yetiştirilmesi & 55.6668 & 0.0509 & 31.4342 & 0.8315 & 15.9973 & 0.0424 & 117.9437 & 0.0001 & 58.1331 & 0.1500 \\
\hline
\end{tabular}

SONUÇ

Sonuç olarak; geçimini tarım ve hayvancılıktan sağlayan ve ülke kalkınmasını doğrudan etkileyen insanların çoğunluğu kırsal kesimde yaşamaktadır. Doğu Anadolu Bölgesi gibi coğrafi şartların ağır olduğu yerlerde ise, ağırlıklı olarak hayvancılık ön plana çıkmaktadır. Hayvancılıkla uğraşan üreticilerin etkin bir şekilde eğitilmesi üretim, gelir ve refah artışının sağlanabilmesi için oldukça önemlidir. Muş ilimizde hayvancılık faaliyetleriyle, özellikle de sığır ve manda yetiştiriciliği ile uğraşan üreticilerin, bu sektörde bilinçlendirilmesi ile hedef kitlenin büyükbaş hayvancılık potansiyellerinin arttırılması mümkün görünmektedir. Çalışmada aşağıda özetlenen sonuçlara ulaşılmıştır:

- Katılımcıların çoğunluğunun genç yaşta olması, bölgede hayvancılık potansiyelinin yüksek oluşu açısından umut vadetmektedir.

- Yetiştiricilerin eğitim seviyelerinin yüksek olmasına rağmen, hayvancılık konusunda eğitim almış olanların oranı oldukça düşüktür. $\mathrm{Bu}$ nedenle, bölgede uygun hayvan besleme yöntemlerinin kullanılmadığı gözlenmiştir.

- Bölgede işletmelerin yeterli hayvan varlığına sahip olmadıkları tespit edilmiştir. 
- Yetiştiricilerin sahip olduğu ekilebilir arazilerinin küçük olması işletmelerin kaba/konsantre yem teminini zorlaştırmaktadır.

- İşletmelerin küçük olması nedeniyle, bölgede tarımsal teknoloji yeterli düzeyde kullanılamamaktadır.

- Üreticilerin büyük bir kısmının hayvanlarını meraya çıkarıyor olması, ekonomik hayvancılık için olumlu görülmektedir.

- Bölgede silaj gibi kaliteli kaba yemlerin üretimi ve kullanımının yetersizliği belirgin bir şekilde görülmektedir.

\section{Çıkar Çatışması}

Yazarlar makaleye eşit oranda katkı sağlamış olduklarını beyan eder.

\section{Yazar Katkısı}

Makale yazarları aralarında herhangi bir çıkar çatışması olmadığını beyan ederler.

\section{KAYNAKLAR}

Akın S, Kara A, Tutkun, M, 2018. Diyarbakır Damızlık Sığır Yetiştiricileri ve Damızlık Koyun Keçi Yetiştiricileri Birliği Özelinde Hayvancılık Destekleri Hakkında Üretici Görüşlerinin Belirlenmesi. Dicle Üniversitesi Fen Bilimleri Enstitüsü Dergisi, 7(1): 21-26

Akkurt M, Köknaroğlu H, 2016. Isparta İli Damızlık Sığır Yetiştiricileri Birliğine Üye Olan Ve Olmayan İşletmelerin Performanslarının Karşılaştırılması Ve Üreticilerin Damızlık Siğır Yetiştiricileri Birliği İle İlişkilerinin İncelenmesi. Süleyman Demirel Üniversitesi Ziraat Fakültesi Dergisi, 11(2):79-90.

Aksoy A, Güler İO, Terin M, 2014. Erzurum İli Damızlık Sığır Yetiştiricileri Birliğine Üye Olan Ve Olmayan Üreticilerin Belirli Özellikler Açısından Karşılaştırılması. Gaziosmanpaşa Üniversitesi Ziraat Fakültesi Dergisi, 31 (3): $82-90$

Anonim, 2021. Muş Tarımsal Yatırım Rehberi 2021. Tarım ve Orman Bakanlığı Strateji Geliştirme Başkanlığı Tarımsal Yatırımcı Danışma Ofisi. https://www.tarimorman.gov.tr/SGB/TARYAT/ Belgeler/il_yatirim_rehberleri/mus.pdf (Erişim tarihi: 13.04.2021).

Arslan Ö, 2018. Muş İli Özelinde Doğal Tarım ve Hayvancılığa Dayalı Sürdürülebilir Bir Ekonomik Gelişim. Anemon, Muş Alparslan Üniversitesi Sosyal Bilimler Dergisi, 6(1): 75-90

Aydın R, Güler O, Yanar M, Diler A, Koçyiğit R, Avcı M, 2016. Erzurum İli Hınıs İlçesi Sığırcılık İşletmelerinin Barınak Özellikleri Üzerine Bir Araştırma. Kahramanmaraş Sütçü İmam Üniversitesi Doğa Bilimleri Dergisi, 19 (1): $98-42$

Bakan Ö ve Aydın R, 2016. Ağrı İli Süt Sığırcılığı İşletmelerinin Sosyo-Ekonomik Özellikleri. Atatürk Üniversitesi Ziraat Fakültesi Dergisi, 47 (2): 113-122

Bakır G ve Demirel M, 2001. Van İli Ve İlçelerindeki Sığırcılık İşletmelerinde Kullanılan Yem Çeşitleri ve Hayvan Besleme Alışkanlıkları. Yüzüncü Yıl Üniversitesi Ziraat Fakültesi Tarım Bilimleri Dergisi, 11 (1): 29-37.

Bakır G ve Kibar M, 2019a. Muş İlinde Bulunan Süt Sığırcılı̆̆ı İşletmelerinin Bazı Yapısal Özelliklerinin Crosstab Analiziyle Belirlenmesi. Kahramanmaraş Sütçü İmam Üniversitesi, Tarım ve Doğa Dergisi, 22 (4): 609-619, DOI:10.18016/ksutarimdoga.vi.512650

Bakır G ve Kibar M, 2019b. Muş İlinde Süt Sığırcıllğ̆ İşletmelerinde Sağlık Yönetiminin Belirlenmesi. Iğdır Üniversitesi Fen Bilimleri Enstitüsü Dergisi, 9 (4): 2409-2419, DOI: 10.21597/jist.533230

Bakır G ve Kibar M, 2020. Muş İli Besi Sığırcılığı İşletmelerinin Bazı Yapısal Özelliklerinin Belirlenmesi. Kahramanmaraş Sütçü İmam Üniversitesi, Tarım ve Doğa Dergisi, 23 (6): 1687-1697, DOI:10.18016/ ksutarimdoga.vi.694060

Bakır G, 2002. Van İlindeki Özel Süt Sı ğırcılığı İşletmelerinin Yapısal Durumu. Yüzüncü Yıl Üniversitesi, Ziraat Fakültesi, Tarım Bilimleri Dergisi, 12 (2): 1-10

Boz İ, 2013. Doğu Akdeniz Bölgesi’nde Süt Siğırcıllı̆̆ Yapan İşletmelerin Yapıs1, Sorunları ve Çözüm Önerileri. Kahramanmaraş Sütçü İmam Üniversitesi, Doğa Bil. Dergisi, 16 (1): 24-32

Budağ C ve Keçeci Ş, 2013. Van'da Büyükbaş Hayvan Besilerinde Kullanılan Yemler ve Besi Şekillerine İlişskin Bir Anket Çalışması. Yüzüncü Yıl Üniversitesi, Fen Bilimleri Enstitüsü Dergisi, 18 (1-2): 48-61

Demir P, Elmalı DA, Işık S, Tazegül R, Ayvazoğlu C, 2013. Kars İli Süt Sığırcılık İşletmelerinde Yem Kullanımı ve Hayvan Besleme Alışkanlıklarının Ekonomik Önemi. Atatürk Üniversitesi Veteriner Bililimleri Dergisi, 8 (3): 229-236 
Demir PA, Işık SA, Aydın E, Yazıcı K, Ayvazoğlu C, 2015. Socio-economic Importance of Sheep Breeding Farms in Ardahan Province. Van Veterinary Journal, 26 (3): 141-146

Esen F, 2017. Bingöl İli’nde Büyükbaş ve Küçükbaş Hayvancılık Faaliyetleri. Bingöl Üniversitesi Sosyal Bilimler Enstitüsü Dergisi, 7 (13): 83-100

Gülsün B ve Miç P, 2018. Rasyon Hazırlamada Temel Yem Miktarlarının Ekonomik Olarak Belirlenmesi İçin Çok Amaçlı Programlama Yaklaşımı. Ömer Halisdemir Üniversitesi, Mühendislik Bilimleri Dergisi, 7 (2): 634-648, DOİ: 10.28948/ngumuh.444657

Güzel M ve Aybek A, 2017. Kahramanmaraş İli Süt Sığırcılı̆̆ı İşletmelerinin Mekanizasyon Yapısı. Kahramanmaraş Sütçü İmam Üniversitesi, Doğa Bilimleri Dergisi, 20 (2): 148-159, DOI : 10.18016/ksujns.88470

Kara A ve Kızıloğlu S, 2013. Meraya Dayalı Hayvancılık Yapan İşletmelerde Optimum Ürün Bileşiminin Belirlenmesi: Erzurum İli Örneği. Atatürk Üniversitesi, Ziraat Fakültesi Dergisi, 44 (1): 63-73

Karadavut U, Genç A, Palta Ç, Çarkacı DA, Kökten K, 2011. Konya İli Yem Bitkileri Üreticilerinin Sosyo-Ekonomik Yapıları ile Başarılı Üretimi Etkileyen Faktörlerin Belirlenmesi. Bingöl Üniversitesi Fen Bilimleri Dergisi, 1 (2): 38-50

Karakuş F, Akkol S, 2013. Van İli Küçükbaş Hayvancılık İşletmelerinin Mevcut Durumu ve Verimliliği Etkileyen Sorunların Tespiti Üzerine Bir Araştırma. Yüzüncü Y1l Üniversitesi, Fen Bilimleri Enstitüsü Dergisi, 18 (1 -2): 0916

Karaturhan B, Şevik T, Yıldız Ö, 2014. Yetiştirici Birliklerinin Tarımsal Kalkınmaya Etkileri Üzerine Bir Araştırma: Edirne Damızlık Sı̆̆ır Yetiştiricileri Birliği Örnek Olayı. Ege Üniversitesi Ziraat Fakültesi Dergisi, 51 (2): 175 184

Özkan U, 2020. Türkiye Yem Bitkileri Tarımına Karşılaştırmalı Genel Bakış ve Değerlendirme. Türk Ziraat Mühendisliği Araştırmaları Dergisi. 1 (1), 29-43

SAS 2014. SAS/STAT. Statistical Analysis System for Windows. Released Version 9.4. SAS Institute Incorporation, Carry, NC, USA

Soya H, Avcıŏlu R, Geren H, 2004, Yem Bitkileri. Hasad Yayıncılık, 223 s.

Şahin K ve Gürsoy AK, 2016. Iğdır İli Süt Sı̆̆ırcılı̆̆ı İşletmelerinin Sosyo Ekonomik Yapısı. Nevşehir Bilim ve Teknoloji Dergisi TARGİD Özel Sayı 118-129, DOI: 10.17100/nevbiltek.210975

Şahin K ve Keskin B, 2010. Van İli Gevaş İlçesinde Yem Bitkileri Üreten İşletmelerin Mevcut Durumu ve Sorunları. Alınteri, 19 (B): 7-13 ISSN:1307-3311

Şahin K ve Yılmaz İH, 2008a. Van İli’nde Yem Bitkileri Tarımı, Mera Kullanımı ve Sosyo Ekonomik Yapı Üzerine Bir Araştırma. Ankara Üniversitesi Ziraat Fakültesi, Tarım Bilimleri Dergisi, 14 (4): 414-419

Şahin K ve Yılmaz İH, 2008b. Van İli Gürpınar İlçesinde Yem Bitkileri Üretimi ve Sorunları Üzerine Bir Araştırma. Tarım Bilimleri Dergisi 14 (1): 16-21.

Şeker İ, Tasalı H, Güler H, 2012. Muş İlinde Sığır Yetiştiriciliği Yapılan İşletmelerin Yapısal Özellikleri. Fırat Üniversitesi, Sağlık Bilimleri Veteriner Dergisi, 26 (1): 9-16.

Terin M ve Ateş HÇ, 2010. Çiftçilerin Örgütlenme Düzeyi ve Örgütlerden Beklentileri Üzerine Bir Araştırma: Van İli Örneği. Ege Üniversitesi Ziraat Fakültesi Dergisi, 47 (3): 265-274

Turan M, 2019. Diyarbakır Manda Yetiştiriciliğinin Mevcut Durumu, Sorun ve Çözüm Önerilerinin Belirlenmesi. Yüksek Lisans Tezi. Dicle Üniversitesi Fen Bilimleri Enstitüsü. Diyarbakır, 2019

TÜİK 2018. Tarımsal İşletme İşücü Ücret Yapıs1, $2018 . \quad$ https://tuikweb.tuik.gov.tr/ PreHaberBultenleri.do;jsessionid=RBs9fYcSLTtyFvHcQCG2Jq49pMb66wHD2yNjJrwcJh2v22JZ85qm!765828690? id=30820 Erişim tarihi: 10.04.2021

Yıldız S, Akkol S, Deniz S, 2019a. Van Yüzüncü Yıl Üniversitesi Dap Çiftçi Eğitim Merkezi’nde Eğitim Alan Kursiyerlerin Tarım-Hayvancılık Okuryazarlığı Kapasitelerinin Değerlendirilmesi. Yüzüncü Yıl Üniversitesi, Fen Bilimleri Enstitüsü Dergisi, 24 (2): 133-141

Yıldız S, Akkol S, Deniz S, 2019b. Van Yüzüncü Yıl Üniversitesi Dap Çiftçi Eğitim Merkezi'nde Eğitim Alan Kursiyerlerin Tarım-Hayvancılık Potansiyellerinin Değerlendirilmesi. Van Veterinary Journal, 30 (3): 151 -157. 